\title{
The Catch of the Hyperreal: Yossarian and the Ideological Vicissitudes of Hyperreality
}

\section{ABSTRACT}

Hyperreality is a key term in Jean Baudrillard's cultural theory, designating a phase in the development of image where it "masks the absence of a profound reality." The ambiance of Joseph Heller's Catch-22 (1961) closely corresponds to Baudrillard's notion of the hyperreal as images persist to precede reality in the fictional world of the novel. Since for Baudrillard each order of simulacra produces a certain mode of ideological discourse that impacts the perception of reality, it is plausible that the characters of this fictional context should be ideologically impacted by the hyperreal discourse. From this vantage point it is possible to have a new critical assessment of Yossarian's (protagonist) antiheroic stance and study the role of the "business of illusion," whose ideological edifice is based on the discourse of the hyperreal, on his antiheroic stance and actions. By drawing on Baudrillard's cultural theory this paper aims to read Heller's novel as a postmodern allegory of rebellion against the hyperreality of the twentieth-century American life and trace its relevance to modern-day U.S.

Keywords: hyperreality, society of spectacle, business of illusion, antihero, Baudrillard. 


\section{INTRODUCTION}

Catch-22 (1961) remains the most studied Heller novel with an ongoing relevance and topicality which continues to extend the wealth of academic materials on its literary merits and cultural significance. Since its publication in early 60 s the novel had been the subject of diverse critical studies ranging from mythological to post-structural examinations. A good example of such studies is Jon Woodson's A Study of Joseph Heller's Catch-22: Going Around Twice (2001) in which he traces a mythical subtext associated with the Sumerian epic Gilgamesh in Heller's novel or David M. Craig's Tilting at Morality: Narrative Strategies in Joseph Heller's Fiction (1997) which also touches on the mythological substructure of the novel, namely Yossarian's archetypal conviction to evade death and live forever, and his similitude to Prometheus in terms of having a "liver condition." On the other hand, the novel is also widely credited as one the earliest instances of postmodern fiction. Gary W. Davis was among the first critics who took note of the novel's postmodern connotations, specifically the "discontinuity between language and reality" that pervades the universe of the novel as reflected in Yossarian's whimsical transformation of meaning while censoring letters or the meaningless "bombing pattern" phrase that General Peckem invents to convince everyone that it is important that the bombs explode close to each other and make a nice aerial photograph (qtd. in McDonald, Reading "Catch-22" 64-68). In Laughing at the Darkness: Postmodernism and Optimism in American Humor (2010) Paul McDonald also touches on the postmodern traits that run throughout the novel; however, his interest is focused on the echo of a different aspect of the postmodern condition in the novel. McDonald asserts that absurdities in the novel like the "bombing pattern" or nailing soldiers together to create eye-pleasing parades are symptomatic and reflective of the "the culture of simulacrum" which has dominated American culture. McDonald argues that the novel echoes what Fredric Jameson calls a "second order of reality," i.e. a symptom of American postmodern culture where images threaten to "take precedence over reality." McDonald goes on to suggest that Yossarian's refrain "they're going to kill me" is not directed at Hitler but those who subscribe to and prevail the "empty surfaces" of the culture of simulacrum:

He comes to see reality as something people ignore in favor of convenient misrepresentations that sustain whichever comfortable delusion or master-narrative they choose to embrace. Yossarian's refrain, “They're trying to kill me," in other words, refers less to Hitler than to those who subscribe to such misrepresentations with no regard for logic, or humanity. (28) 
McDonald's analysis of Yossarian's refrain and character opens an avenue to look at the idiosyncrasies of this intricate character from a new perspective. This is the task which this paper undertakes in what follows, but before that I consider it necessary to discuss Yossarian's idiosyncratic dangling between the poles of heroism and its opposite: antiheroism. While in the eyes of the likes of Woodson, Craig and Davice he stands as a mythological/postmodern/counterculture hero, literary scholars such as M. H. Abrams, J. A. Cuddon and Ihab Hassan consider him to be a perfect example of what is labeled as "antihero." In his essay "The Antihero in Modern American and British Fiction" (1959) Hassan designates antiheroes as different types of victims:

In fiction, the unnerving rubric "antihero" refers to a ragged assembly of victims: the fool, the clown, the hipster, the criminal, the poor sod, the freak, the outsider, the scapegoat, the scrubby, opportunist, the rebel without a cause, and the hero in the ashcan and hero on the leash. (55)

Many of the labels that that are listed above are descriptive of Yossarian; his clownish demeanor, outsider stance, and final rebellion, to name but a few, make him an ideal example of Hassan's designation of this literary trope. However, his antiheroic stance is mainly embodied in his overwhelming fear of death which forces him to circumvent duty at any cost; poisoning the soldiers' food, sabotaging military maps, or faking illness are among the many measures he takes to postpone or avoid flying missions. While Yossarian's fear of death and antiheroic stance is constantly conveyed to the reader, no clear explanation for his behavior is provided. What this article aims to accomplish is to pin down the underlying reasons for Yossarian's antiheroic stance in the light of the "culture of simulacrum" in which he was assimilated. First, it is important to note that the "culture of simulacrum" is not a term coined by Jameson as McDonald presumed. As Jameson explains in his article "Periodizing the 60s," later assimilated in the volume The Ideologies of Theory (1988), "the culture of simulacrum" was an idea developed out of Plato's theory of forms by Gilles Deleuze and Jean Baudrillard, designating a state of reproduction where there is no original for the made copies (195). According to Jameson its conceptualization is also indebted to the writings of the French situationist Guy Debord:

This omnipresence of pastiche is not incompatible with a certain humor, however, nor is it innocent of all passion: it is at the least compatiblewith addiction - with a whole historically original consumers' appetite for a world transformed into sheer images of itself and for pseudoevents and "spectacles" (the term of the situationists). It is for such objects that we may reserve Plato's conception of the "simulacrum," the identical 
copy for which no original has ever existed. Appropriately enough, the culture of the simulacrum comes to life in a society where exchange value has been generalized to the point at which the very memory of use value is effaced, a society of which Guy Debord has observed, in an extraordinary phrase, that in it "the image has become the final form of commodity reification." (17)

The concluding quote from the above passage is taken from Debord's influential text The Society of the Spectacle (1967). Debord explains "spectacle" as an assertive confirmation of the regulation of appearances over all aspects of social life. The first phase of economy's monopoly over social life caused a debasing shift from evaluating humans as who they are to evaluating them based on what they have. However, in the present stage, "havings" should derive their prestige and final goals from the appearances. This has brought about yet another shift, this time "from having to appearing" (Debord 11). Therefore, the late twentieth century gave birth to a grand spectacle which replaced the real world with a world of images in which the social relations between the members of society are mediated via image. Debord suggested that the rise of this spectacular culture has generated "a second nature with its own inescapable laws" which dominates our daily awareness (13). Debord's writings preceded and influenced the writings of Jean Baudrillard, the main theorist on the "culture of simulacrum." For Baudrillard socio-cultural life in latetwentieth century had surpassed the level of "spectacle" and had reached a more radical phase. Hyperreality is the key term that Baudrillard uses to describe this new stage in the relationship between image and reality, namely the phase where simulacra (image) "masks the absence of a profound reality" (Simulacra and Simulation 8). In Baudrillard's vision the progression of the relationship between reality and its representation (image) falls into four main phases: "it is the reflection of a profound reality; it masks and denatures a profound reality; it masks the absence of a profound reality; it has no relation to any reality whatsoever; it is its own pure simulacrum" (8). The emergence of the hyperreal order coincides with the inauguration of the third phase of simulacra and extends into the fourth one (see section 1.3 for a full discussion on hyperreality).

The centrality and omnipresence of the United States in Baudrillard's writings is a renowned feature of his study of postwar era, as it is reflected in his comment that "all of the themes that I first examined in my previous books suddenly appeared in America, stretching before me in concrete forms" (qtd. in Rubenstein 11). Baudrillard's interest in the United States and his critical writings on its "hyperreal" status makes his theory a suitable intellectual background to examine the reflection of a hyperreal 
America in Heller's war novel. This article aims to argue that Yossarian's antiheroic stance and status are shaped by hyperreality as his perceptions and actions are conditioned by its discourse. It is worth mentioning that "for Baudrillard, each order of simulacra produces knowledge, ideas and perceptions that maintain and reproduce the power relations of that order"(Pawlett 73). Hence, hyperreality is treated as a hegemonic discourse in this paper and the extent to which Yossarian's subjectivity is ideologically conditioned by it is attested by reference to many events of the novel. In the first section of this article the hyperreal status of Pianosa island, where the events of the novel take place, is compared to Disneyland and the continuing relevance of Heller's novel for the modernday U.S. is discussed. In the second section, Yossarian's antiheroic stance is explicated as a symptom of the domination of the hyperreal discourse over his subjectivity. In the third section, Yossarian's encounters with the embodiments of the orders of simulacra are fully detailed. Finally, in the fourth section, Yossarian's transition from an antiheroic stance to a heroic one is explained in terms of his adopting the role of Baudrillardian "Evil" and rebelling against the hegemony of the hyperreal.

\section{BoDY OF Discussion}

\section{1. $C A T C H-22$ AND DISNEYLAND}

In his reading of Catch-22 Paul McDonald concentrates on instances in which a fascination with images critiques "a TV culture which has a corrupting influence on how we perceive reality" and quoting from Neil Postman, "we have adjusted to what may have at one time been termed "bizarre" (Reading "Catch-22" 29). Lieutenant Scheisskopf's obsession with creating eye-pleasing parades in which the hands of the soldiers remain immobile or Peckem's fabrication of a "bombing pattern"1 are among the examples that McDonald provides in his reading. We can supplement McDonald's reading with other examples from the novel. The preoccupation of American culture with the "bizarre" is embodied in its generation of trends such as celebrity worship or paparazzi, and both of these corresponding trends are satirized in the novel: Hungry Joe introduces himself as an important photographer from Life magazine to cajole Italian girls to pose naked for him, wheedling them with promises like " $[\mathrm{b}]$ ig picture on heap big cover.

A meaningless term Peckem fabricates to convince everyone that "it's important for the bombs to explode close together and make a neat aerial photograph" (Heller 222). 
Si, si, si! Hollywood star. Multi dinero. Multi divorces. Multi ficky-fick all day long" (34). Also, in a typically Paparazzian style, he bursts into the room where Yossarian and Luciana are making love to take photographs of them (he keeps pursuing this task on multiple other occasions). On the other hand, the predicament of celebrity worship is epitomized in Major Major Major who suffers from resemblance to Henry Fonda. Contrary to Fonda, Major Major Major is the personification of mediocrity so that "even among men lacking all distinction he inevitably stood out as a man lacking more distinction than all the rest" (Heller 56), as a result of which he had to apologize to everyone for not being Henry Fonda.

The fact that most of these characters possess top military ranksGeneral, Lieutenant, Major, etc.- - and serve as authorial figures brings about expectations in terms of their maturity and rational conduct. However, their blatant obsession with appearances renders their actions childish and immature so that it seems like these top military ranks are filled by children rather than serious adults. How can such rampant childishness be explained? Where does it come from? To answer these questions we should draw on Baudrillard's analysis of Disneyland as a place symptomatic of American culture. Baudrillard considered Disneyland as an objective miniaturized replica of the United States where features such as American lifestyle, values, or even individual American characteristics could be easily detected:

It is a deterrence machine set up in order to rejuvenate the fiction of the real in the opposite camp. Whence the debility of this imaginary, its infantile degeneration. This world wants to be childish in order to make us believe that the adults are elsewhere, in the "real" world, and to conceal the fact that real childishness is everywhere, particularly among those adults who come here to act the child in order to foster illusions as to their real childishness. (Simulacra and Simulation 12-13)

The childish behaviors of the characters that populate Heller's novel are in line with the rampant childishness which, according to Baudrillard, has eclipsed American image-centered society. For Baudrillard Disneyland stands for this society and transcends the level of an imaginary entertainment center:

Disneyland is presented as imaginary in order to make us believe that the rest is real, when in fact all of Los Angeles and the America surrounding it are no longer real, but of the order of the hyperreal and of simulation. It is no longer a question of a false representation of reality (ideology), but of concealing the fact that the real is no longer real, and thus of saving the reality principle. (12) 
In America (1986) he even goes further to propose that "[i]f you believe that the whole of the Western world is hypostatized in America, the whole of America in California, and California in MGM and Disneyland, then this is the microcosm of the West" (America 54-55). From this perspective, it is arguable that similar to Disneyland the fictional island of Pianosa, where the events of the novel are taking place, stands as a miniature duplicate of United States as it mirrors its hyperreal society of spectacle. However, the difference is while the function of Disneyland is to somehow obscure the hyperreality of twentieth century American life, the events in Pianosa island operate to illuminate that fact. Furthermore, the fact that the novel's most extreme cases of childishness belong to the highest officials sends a political message pertaining to the subservience of the ruling system to the rules of spectacle. This is to say that the governing system is nothing more than a simple gag within the bigger machinery of the spectacle. A good example for this fact is the 2008 American primary election where Hillary Clinton and Barack Obama fought over Democratic nomination. Throughout their competition, policies and standards were so overshadowed by the precedence of appearances that images became a signal for reliability, suitability or trustworthiness (Toffoletti 15). However, perhaps, we do not need to look as far back as 2008 election to take note of the continuing dominance of "spectacle" over American culture and the relevance of Heller's novel for modern-day America. Following the election of Donald Trump as the $45^{\text {th }}$ president of United States, Robert Zaretsky published an article in New York Times under the title "Trump and the 'Society of the Spectacle." According to Zaretsky:

\begin{abstract}
With the presidency of Donald Trump, the Debordian analysis of modern life resonates more deeply and darkly than perhaps even its creator thought possible, anticipating, in so many ways, the frantic and fantastical, nihilistic and numbing nature of our newly installed government. In Debord's notions of "unanswerable lies," when "truth has almost everywhere ceased to exist or, at best, has been reduced to pure hypothesis."
\end{abstract}

Zaretsky goes on to pose questions regarding the spectacular aspect of Trump's presidency, including "[w]ho can separate the real Trump from the countless parodies of Trump and the real dangers from the mere idiocies?" or "[i]s it possible we are all equally addicted consumers of spectacular images he continues to generate? Have we been complicit in the rise of Trump, if only by consuming the images generated by his person and politics?" Zaretsky's questions not only reflect Debord's perspective but also touch on the heart of Baudrillard's theory, namely when he asks 
"[w] ho can separate the real Trump from the countless parodies of Trump" he is_-perhaps unknowingly_evoking one of Baudrillard's key concepts: hyperreality. ${ }^{2}$ It is against this background that we can discern the resonances of Heller's novel in the modern day United States, a country where images precede reality and make presidents out of TV personalities. It is precisely against this backdrop that we can analyze the antiheroic stance and status of Yossarian.

\subsection{YOSSARIAN AND THE "BUSINESS OF ILLUSION"}

Among the schemes that Yossarian devices to avoid flying missions, faking illness is the most persistent one as he keeps moving to and from hospital throughout the narrative. His mysterious liver condition and the response of military Doctors to it serve as a good starting point to study his antiheroic status in the light of Baudrillard's theories. In Simulacra and Simulation (1981) Baudrillard differentiates between the acts of simulating and dissimulating illness:

To dissimulate is to pretend not to have what one has. To simulate is to feign to have what one doesn't have. One implies a presence, the other an absence. But it is more complicated than that because simulating is not pretending: "whoever fakes an illness can stay in bed and make everyone believe that he is ill. Whoever simulates illness produces in himself some of the symptoms" (Littre). Therefore, pretending, or dissimulating leaves the principle of reality intact: the difference is always clear, it is simply masked, whereas simulation threatens the difference between the "true" and the "false," the "real" and the "imaginary." Is the simulator sick or not, given that he produces "true" symptoms? Objectively one cannot treat him as either ill or not ill. (3)

Therefore, illness simulation blurs the lines between "true" and "false" or "real" and "imaginary" illness because the simulator cannot be objectively diagnosed as either ill or not ill. Medicine faces crisis in this case since if symptoms are artificially producible any illness could be viewed as simulated and medicine loses sense since it is only cable of treating real illnesses (3). This is the case that the doctors who are treating Yossarian are faced with since his illness blurs the lines between real and fake illness: he is hospitalized because of

a pain in his liver that fell just short of being jaundice. The doctors were

2 The inability to distinguish the real Trump from his parodies is symptomatic of the hyperreal condition where "there is no original for the made copies." 
puzzled by the fact that it wasn't quite jaundice. If it became jaundice they could treat it. If it didn't become jaundice and went away they could discharge him. But this just being short of jaundice all the time confused them. (Heller 1)

The nature of Yossarian's medical condition which fluctuates between being jaundice and not being jaundice intrinsically mimics the effects of simulation par excellence as it defies the possibility of discerning truth from simulation. As Baudrillard appropriately questions "what can medicine do with what floats on either side of illness, on either side of health, with the reduplication of illness in a discourse that is no longer either true or false?" (Simulacra and Simulation 3-4). By falling short of being jaundice, Yossarian's liver condition vacillates or "floats" between illness and health, and thus renders medical authority helpless. Furthermore, his liver condition materializes Baudrillard's well-known diagnosis of hyperreality as "substituting the signs of the real for the real" (4). In an ambiguous dialogue with Milo Minderbinder the antihero claims: "I don't really have a liver condition. I've just got the symptoms" (Heller 40). The signs of the illness replace the real illness in this case. In addition to this, the narrative obfuscates the true status of this liver problem to the level of sheer indeterminacy. In the chapter "The Soldier Who Saw Everything Twice," Yossarian pretends to have pain in his appendix and rushes to hospital to avoid combat duty. However, the attending doctor explains to him that having an appendix problem is not a suitable ailment for circumventing duty since it can be taken out immediately and he has to leave hospital, yet he urges him to "come to us with a liver complaint and you can fool us for weeks"(Heller 120). Given that the novel has a non-linear form and the sequence of events is chronologically disordered, it is to be presumed that this encouragement is what triggers Yossarian's constant liver condition throughout the novel. This fact contradicts what we read in the first page of the novel which implies he actually had some pain in his liver: "Actually the pain in his liver had gone away, but Yossarian didn't say anything and the doctors never suspected" (Heller 1). What is more significant is the reaction of medical authority to this act of simulation. When Yossarian bluffs to Doc Daneeka about the mysterious pain in his liver which has confused nurses and doctors alike since it neither becomes jaundice nor vanishes away, Doc Daneeka does not question the eccentricity of his medical condition. $\mathrm{He}$ simply takes Yossarian's claim at face value and writes this order on a piece of paper: "give Yossarian all the dried fruit and fruit juice he wants, he says he has a liver condition" (40). The reaction of the hospital doctors to Yossarian's claim also parallels Doc Daneeka's model: they readily accept Yossarian's claims about his condition. This unquestioning acceptance of 
Yossarian's claims on the part of the medical authority is quite surprising, especially provided that - as it is later revealed in the novel - they are fully aware that Yossarian is lying. However, Baudrillard would not find the reaction of these military doctors surprising:

What can the army do about simulators? Traditionally it unmasks them
and punishes them, according to a clear principle of identification. Today
it can discharge a very good simulator as though he were equivalent to
a "real" homosexual, heart-case or a madman. Even military psychology
retreats from the Cartesian clarities and hesitates to draw the distinction
between true and false, between the "produced" symptom and the
authentic symptom. (Simulacra and Simulation 4)

The full proportions of refusing to distinguish the true from the "produced" is best exposed once we return to the aforementioned advice that Yossarian received from a doctor on how to improve the feasibility of his illness simulation. What is most significant in this case is the complicity of authority (in this case medical authority) in the production of simulation. By withdrawing from discriminating between authentic symptoms and "produced" ones they stimulate simulation; they also instruct in the best methods for masking the truth to the point of unrecognizability. This being said, the emerging question is-what is the rationale behind such extreme reluctance to distinguish the true from the fake? The key to this question can be found in yet another episode of the novel involving Yossarian, doctors, and simulation. This time instead of simulating illness he has to simulate dying. He is asked by one of the doctors to play the role of a dying son for the family of a soldier who is already dead for a few minutes, so they will have the opportunity to meet their dying son for the last time. The doctor offers a deal to Yossarian, proposing that if he cooperates with him he would not reveal that he is lying about his liver condition while explaining that he is fully aware that he is faking it: "how do you expect anyone to believe you have a liver condition if you keep squeezing the nurses' tits every time you get a chance? You're going to have to give up sex if you want to convince people you'e got an ailing liver" (Heller 124). Yossarian becomes baffled and when he expresses immense surprise about the fact that the doctor knew the truth but did not divulge it, he is answered by a sentence that sums up the whole rationale behind this ubiquitous desire for not discerning the original from the produced: "We're all in this business of illusion together" (124). The doctor's confession reveals that the saturation of intersubjective relations by the discourse of simulation is to the extent that the relations of power between the authority (medical authority and the army) and their subjects (soldiers) are quite transformed, i.e. both are equally complicit in carrying 
the plot of masking the truth in favor of the fake. Yossarian's simulation provides the doctor a suitable leverage for making him take part in yet another act of simulation. This on-going process of stimulating simulation, in which every act of simulation inevitably leads to further acts of simulation, culminates in the production of a long chain of simulations whose beads are interdependent upon each other. By yoking the communal and interpersonal relations of the subjects together, this chain leads to the generation of the illusion-centered ambience which pervades the universe of the novel. In addition to this, the doctor's answer to Yossarian also serves as a reminder of Debord's assertion that "the spectacle cannot be understood as a mere visual deception produced by mass-media technologies. It is a world-view that has actually been materialized, a view of a world that has become objective" (7). "The business of illusion" is thus the materialized world-view that reigns over the spectacular context of the novel, a context in which the hegemony of the spectacle has so deeply penetrated and homogenized the characters that deviation from its norms is not even conceivable for them, e.g., the soldier who saw everything twice was not lying about his condition yet the hegemony of the business of illusion had so influenced Yossarian that he not only viewed this soldier as a master of simulation but also started to emulate him to lengthen his own stay in the hospital. Only when this soldier finally dies does Yossarian discover that he was not feigning his symptoms and actually saw everything twice. From this perspective, the basis of Yossarian's antiheroic stance can be explained according to his assimilation within the omnipresent discourse of hyperreality. What essentially designates him as an antihero and seeds his fear of death throughout the novel is his indifference to the ideals which explained and justified the war for everybody else. Ideals pertinent to the war such as heroism, patriotism, democracy or fighting against the evil of Nazism which justified the war for the majority of those who were involved in it did not have the slightest meaning to Yossarian. As the narrator informs us, the protagonist exclusively regarded survival as a valuable ideal:

It was a vile and muddy war, and Yossarian could have lived without it-lived forever perhaps. Only a fraction of his countrymen would give up their lives to win it, and it was not his ambition to be among them. To die or not to die, that was the question. . . History did not demand Yossarian's premature demise, justice could be satisfied without it, progress did not hinge upon it, victory did not depend on it. That men would die was a matter of necessity; which men would die, though, was a matter of circumstance, and Yossarian was willing to be the victim of anything but circumstance. (Heller 45)

The question is why notions such as "justice" or "victory"-alongside 
the aforementioned nationalistic causes-have no hegemonic power over Yossarian to convince him dying in this war can be heroic. The underlying basis of Yossarian's antiheroic stance and the answer to this question could be explained by investigating the effects of the dominance of hyperreal hegemony, and the fact that its discourse had a greater influence on Yossarian than rival discourses-including those of patriotism. As was previously mentioned, the most notable side effect of the domination of the discourse of hyperreality over a given context is the obfuscation of the determinacy between the fake and the real. Yossarian is implicated in an ambience which is totally subsumed by such discourse and indeterminacy, so that everywhere he is surrounded by its symptoms and manifestations. As a result of this, his eyes are screened by the ideological glasses of hyperreality and he looks at his surroundings through the lens of this spatially and temporally dominant discourse. This being said, it is no wonder that ideals such as patriotism, progress, justice or heroism have little credit for Yossarian: their truth and authenticity is undermined by the illusion-based discourse of hyperreality. As Baudrillard explains, "the era of simulacra and of simulation" is marked by "no longer [having] a Last Judgment to separate the false from the true, the real from its artificial resurrection, as everything is already dead and resurrected in advance" (Simulacra and Simulation 8). Simulation proceeds by negating the possibility of distinguishing the real from the non-real and Yossarian is so absorbed in this negation that determining the authenticity of notions such as patriotism, justice, and heroism remains as elusive for him as distinguishing the authenticity of the symptoms of the soldier who saw everything twice. They might or might not have basis in reality and, as the case of the soldier who saw everything twice verifies, a resolute assessment of their reality principle could turn out to be distinctly erroneous.

There are numerous examples within the novel which affirm such a reading of Yossarian's condition and point to his condescending skepticism about the validity of hero-making ideals, especially patriotism: for example, the "educated" Texan from Texas "patriotically" believed "that people of means-decent folk—should be given more votes than drifters, whores, criminals, degenerates, atheists and indecent folk-people without means" (Heller 4). Texan, on account of his nationalistic views, is referred to as the "patriotic Texan" throughout the novel and his patriotism is "donated" to and echoed by Dunbar as well, who after listening to him cries "that's it, there was something missing-all the time I knew something was missing - and now I know what it is. No patriotism" (4). Although Texan's and Dunbar's alleged patriotism is, it seems, satirically irrational, it is not regarded as such by Yossarian. In response to Dunbar's words he retorts: 
You're right, you're right, you're right. The hot dog, the Brooklyn Dodgers. Mom's apple pie. That's what everyone's fighting for. But who's fighting for the decent folk? Who's fighting for more votes for the decent folk? There's no patriotism, that's what it is. And no matriotism, either. (4)

Yossarian's haphazard remarks touch on the foundation upon which the ideological edifice of patriotism is erected: "Hot dog," "Brooklyn Dodgers," and "Mom's apple pie" are symbolic representatives of the very ingredients which compose American patriotism, i.e. patriotic discourse mainly mobilizes masses under the banner of protecting indigenous cultural riches (hot dog, Brooklyn Dodgers) and domestic values (Mom's apple pie) against the threat of foreign intruders who seek to take them away from the indigenous nation. Thus, from this perspective, heroism in war is at least partly dependent on entirely cultural factors that are echoed in Yossarian's remarks but ironically are totally meaningless to him. Through a mocking endorsement of Texan's and Dunbar's literal fascism (something against which they are supposed to be fighting) and negating the domestic values which "everybody is fighting for," Yossarian flagrantly parodies their presupposed significance. Yet he doesn't stop there, and by a satirical juxtaposition of patriotism with "matriotism" further parodies the ideological basis of patriotic discourse. Furthermore, this extensive dismantling of presupposed values culminates in Chaplain's act of transgression: Chaplain is portrayed throughout the novel as an epitome of faith in righteousness who is one hundred percent subservient to his ethical ideology, contrasting with the likes of Yossarian or Doc Daneeka who find ideological principles meaningless. Yet, following in his footsteps, he lies about being sick in order to get checked into the hospital. Chaplain's act of transgression follows no purpose. He sins just for the sake of sinning and afterwards he is able to rationalize his transgression to himself in a way that convinces him he has not sinned at all. The conclusion that Chaplain draws from this experience perfectly illustrates the devaluation of moral certitudes under the hegemony of hyperreal discourse: "It was almost no trick at all, he [Chaplain] saw, to turn vice into virtue and slander into truth, impotence into abstinence, arrogance into humility, plunder into philanthropy, thievery into honor, blasphemy into wisdom, brutality into patriotism, and sadism into justice" (Heller 248).

\subsection{YOSSARIAN AND THE ORDERS OF SIMULACRA}

Chaplain's conclusion is a further confirmation of the obfuscation and the arbitrary disposition of the reality principle under the hegemony of the hyperreal. A phenomenon which finds further embodiment in the 
death of the soldier in white: this unnamed and unidentified soldier is so heavily injured that he is described as being made of gauze, plaster and a thermometer, which plays the role of mere adornment for this mummified body which has a black hole for a mouth and the thermometer is placed in it at morning and removed from it in afternoon on a daily basis. The immobility and muteness of the soldier in white is to the extent that the very possibility of the existence of a living being within the caste of plaster and gauze is questionable for the other inmates. His survival is dependent on two tubes connected to his elbow and groin, transferring nutrition to his body and disposing its waste. The condition of soldier in white parallels what Slavoj Žižek describes as being "between two deaths: dead while still alive” (167). Žižek provides many cinematic examples of this phenomenon among which Ivan Reitman's Dave (1993) stands out as the most pertinent one to the case of the soldier in white: in this movie the U.S. President is reduced to the level of an immobile vegetable after suffering a huge stroke. The Secret Service replaces the paralyzed President with Kevin Kline's title character, an ordinary man who impeccably resembles the President. At the end of the movie, simultaneous with the proclamation of the real President's death (which is untrue), Kline engineers his own disappearance while being joined by the President's wife who has fallen in love with him. Žižek interprets Kline's role-playing as the President as being located "between two deaths," i.e. the metaphorical death of the President (complete paralysis standing as a symbolic equivalent for death) and his social death followed by the official declaration of his death (undermining his biological subsistence). However, Žižek believes that in this case the genuine embodiment of being "between two deaths" is located in the image of the real President himself:

In the triad of the "real" President, his stand-in, and the Presidency as the symbolic place, which can be occupied by different actual individuals, the key image is that of the incapacitated "real" President in a secret room beneath the White House, attached to a life-support machine-so, ultimately, the one who is "between two deaths" is the "real" President himself: he is still alive while socially already dead, reduced to a level of pure biological subsistence. (168)

Is not the plight of the President in Reitman's film similar to the predicament of the soldier in white? Is he not also placed between two deaths and experiences death twice? And is this not yet another example for the confusion of the real and the fake (in this case real death)? The covering of the soldier's entire body in gauze and plaster which rendered him motionless and speechless, like the vegetable state of the President, 
signaled his symbolic death, while his social death occurred when Nurse Duckett declared him officially dead on one occasion when she was removing his thermometer. However, since the soldier in white is fully covered in gauze this announcement is not confirmed by any visible change in his appearance or bearing; the connected tubes to his body kept inserting and retracting fluids into it and from it. Nurse Duckett's assertion of his death is the only existing fact to rely on and, like Yossarian's claim to have a liver condition, it goes undisputed. Once again no desire for preserving the reality principle is perceivable and the veracity of a statement goes uninvestigated. There is no reason not to assume that, as in the case of the President in Reitman's film, the soldier is, at least technically, still alive. Also, in both cases, a formal proclamation is the "death knell" that ends whatever life these two characters had. This is precisely why Yossarian believed that Nurse Duckett had "murdered" the soldier in white:

if she had not read the thermometer and reported what she had found, the soldier in white might still be lying there alive exactly as he had been lying there all along.... Lying there that way might not have been much of a life, but it was all he had, and the decision to terminate it, Yossarian felt, should hardly have been Nurse Duckett's. (Heller 113)

Yossarian's reaction once again highlights the priority and importance of the image in his mind: for him, the termination of the image equates to murder for him. The motionless figure of the soldier in white, covered entirely in bandages, surely revealed little signs of life. Nevertheless, it constituted an image: the image of an injured soldier who is not yet dead and is struggling to live and regain his health. Regardless of the extent of the veracity and the reliability of this image, given that the soldier is mortally wounded and already dead in many ways, it persisted until the very moment that Nurse Duckett destroyed it by announcing the soldier's death. The fact is the the soldier's recovery was out of the question, both to the nurses and to the rest of the ward (who even suspected there was nothing within the bandages and that the soldier was sent there as a joke). Yet, regardless of the unchanging condition of his physical health, his image as a recovering soldier remained fully intact until the nurse terminated it. In other words, it is the termination of this image which caused the soldier's social death and is synonymous with it. Yossarian's view of the death of the soldier in white as an act of murder by Nurse Duckett precisely touches on this point. However, it also once more draws attention to the obsession of the antihero with the role of image and representation, an obsession which is voiced on a collective level once the soldier in white reappears in the ward. Upon returning from a "Hollywood extravaganza in Technicolor," 
the inmates discover the soldier in white back in his old place and in his old condition. Dunbar's screaming that "he is back" is first echoed by a feverishly delirious patient and then by the whole ward, which erupts into total chaos. Patients and injured soldiers start running as if the place is on fire. Still, what is even more haunting than the bedlam that follows the apparent reappearance of the soldier in white is Yossarian's conviction that it is indeed the same man:

"He is back, he is back!" It was, indeed, the same man. He had lost a few inches and added some weight, but Yossarian remembered him instantly by the two stiff arms and the two stiff, thick, useless legs all drawn upward into the air almost perpendicularly by the taut ropes and the long lead weights suspended from pulleys over him and by the frayed black hole in the bandages over his mouth. He had, in fact, hardly changed at all. (Heller 248)

The underlying reason for Yossarian's presumption that the newly arrived injured soldier is the same soldier in white, who has returned from the realm of the dead, goes one step beyond his obsession with appearances. It is symptomatic of the Baudrillardian third order of simulacra and another confirmation of the extent to which Yossarian's universe, and thus American culture generally, is overshadowed by hyperreality. Essentially, Baudrillard's orders of simulacra register the evolutionary phases of the image: "from reflecting reality, to masking reality, to masking the absence of reality, to having no relation to reality whatsoever" (Toffoletti 17). While in the first order of simulacra the original referent is distinguishable from its counterfeit or image, the second order "blurs the boundaries between reality and representation" (Lane 86), as evidenced in Andy Warhol's Campbell's Soup Cans: this work of art is comprised of 32 canvasses, each illustrating one can, all of them looking entirely identical minus their different labels. All of the images are printed from one single silkscreen template so that not only distinguishing between them becomes impossible but also none of them can be conceived as the original from which the rest have been copied (Toffoletti 21-22). At first glance, akin to Warhol's Cans, the phenomenon of the soldier in white might appear as an incarnation of the second order of simulation. However, closer inspection reveals that this is not the case since, unlike Warhol's artworks, the soldier in white phenomenon draws upon no external referent. While the extreme similitude between Warhol's cans has made them substitutable for one another so that none of them stands as the original version, they still remain representational copies from a real model-the actual cans of Campbell Soup Company. Comparably, the soldier in white is a dehumanized figure 
reduced to the level of a meager image - that of a mummified, immobile and mute effigy, substitutable by other identical images - something which actually takes place in the novel. However, unlike Warhol's Campbell Cans, the twin images of the soldier in white are anchored to no external referent; they are copies without an original model. Thus, the phenomenon of the soldier in white belongs to the third order of simulacra: the order of the hyperreal, where "images circulate freely, detached from any concrete association with an object in the real world, hence can accrue meaning in relation to each other" (Toffeletti 24). In this context, it is significant that the reappeared figure of the soldier in white is discovered once the inmates return from a "Hollywood extravaganza in Technicolor" (Heller 248). In Dialectic of Enlightenment (1944) Max Horkheimer and Theodor W. Adorno argue that, by seeking to reproduce the empirical world of everyday perception, films have become the prototype of reality, so that after leaving the cinema the moviegoer perceives the outside street as a continuation of the movie he has just watched. The more impeccably a film succeeds in recreating the objective external world, "the more easily it creates the illusion that the world outside is a seamless extension of the one which has been revealed in the cinema" (Horkheimer and Adorno 99). Therefore, the motion picture that the inmates viewed prior to returning to the hospital served the role of a catalyst which fueled their sense of illusion since "life is to be made indistinguishable from sound film" (99). This is in line with Baudrillard's description of United States as a place where "even outside the movie theatres the whole country is cinematic (America 54)." The spectator leaves the movie theatre to confront a bigger spectacle: "Where is the cinema? It is all around you outside, all over the city, that marvellous, continuous performance of films and scenarios" (54). In a similar fashion, the characters left the Hollywood spectacle to step into the yet bigger spectacle of their everyday reality and thus were fully prepared to take part in its world of illusions. This rings particularly true in relation to Yossarian who is one hundred per cent sure he is confronted with the same man [the soldier in white] and he "would recognize him anywhere" (Heller 249). The fact is that his fixation on "the business of illusion" was already wellestablished, yet what happened pushed him completely over the edge and prompted him into a full acceptance of the hyperreal.

Internalizing the discourse of the hyperreal and embracing its sense of reality not only aggravated Yossarian's paranoia. It also taught him how to manipulate the "precession of simulacra" to his own advantage and to cancel a dangerous mission that he feared would result in his death: Yossarian was fully convinced that he was going to die in the mission to Bologna, a city which could not be conquered by the ground forces. To cancel the mission he tiptoes into the maps tent during the night and moves the bomb 
line, a red ribbon which specified the position of Allied infantry forces on the map, over the city of Bologna. The next morning every military official was convinced that the city was captured and that the mission was canceled. What is at work here is closely related to Borges's short story On Exactitude in Science, a tale used by Baudrillard as his starting point in Simulacra and Simulation. In the story the cartographers of an ancient Empire create a map so identical to the territory of the Empire that it ends up fully covering it. However, following the decline of the Empire the map deteriorates and only its shreds remain. Baudrillard describes the tale as an instance of second order simulacra which is succeded by the hyperreal in the modern era:

Today abstraction is no longer that of the map, the double, the mirror, or the concept. Simulation is no longer that of a territory, a referential being, or a substance. It is the generation by models of a real without origin or reality: a hyperreal. The territory no longer precedes the map, nor does it survive it. It is nevertheless the map that precedes the territory-precession of simulacra - that engenders the territory, and if one must return to the fable, today it is the territory whose shreds slowly rot across the extent of the map. It is the real, and not the map, whose vestiges persist here and there in the deserts that are no longer those of the Empire, but ours. The desert of the real itself. (1)

Is not the "precession of simulacra" as Baudrillard delineates in the above paragraph materialized in the incident with the map? Unlike the map in Borges' story the map in Catch-22 precedes the territory and any alteration to it guarantees an alteration in reality-at least in the mind of the paranoid residents of Pianosa Island. The high ranked army officials readily accepted the alteration of the bomb line's position as infallible proof of the conquest of the named city. Even though they were fully aware that the ground forces were in no position to accomplish this task, the map's forged claim on the conquest of Bologna is as undisputedly welcomed and embraced by military authority as Yossarian's feigning of illness was embraced by the medical authority. This fact once again points to the simulation-centered ideology which directs the characters' mode of thought and action. Yet, the true importance of the incident with the map is in its highlighting of a remarkable shift in terms of the antihero's interaction with simulation. In his antiheroic fear of death and impulsive desire to circumvent duty Yossarian makes a huge leap from a minor simulation of illness to a major manipulation of simulacrum. In the first case nobody was harmed by his conduct but the latter case led to the possible demise of Major De-Coverley. Although moving the bomb line did not fool the enemy it surely deceived Major De-Coverley (misled by 
the bomb line's position, he is under the impression that Florence was also captured so he flies there to rent apartments for soldiers on lease) and caused his disappearance. Major De-Coverley's case can be considered an example of the violence of the hyperreal but this does not make Yossarian any less culpable. He can be blamed for the possible death of Major DeCoverley as much as he is responsible for the death of Kraft and his crew in the Ferrara mission: out of excessive fear he couldn't get the target the first time so he made a second turn to bomb it again which resulted in the death of Kraft and his crew. Nevertheless, in both cases it is difficult to perceive any trace of guilt or self-condemnation in Yossarian. Although he frankly admits to being responsible for Kraft's death he seems completely untroubled by it, as is evidenced by his "always almost forgetting Kraft when he counted the dead men he knew" (Heller 274). Analogous to his indifference to patriotic values, morality and ethical stances are also alien to him. It appears that the truth-effacing simulative ambience of the novel has discredited all sorts of values and principles so that the antihero, along with some characters close to him, are left with a moral abyss in which standing up even for righteous principles is viewed contemptuously. This is evident in Doc Daneeka's condemnation of Dr Stubbs: "he is going to give the medical profession a bad name by standing up for principle" (Heller 238). Dr Stubbs stands up to Colonel Cathcart and Colonel Korn and grounds soldiers out of pity. What he does is quite rare within the universe of the novel, and the likes of Doc Daneeka and Yossarian are not able to comprehend it. Nevertheless, Yossarian does not remain a onedimensional character and starts to change late in the novel.

\subsection{YOSSARIAN'S REBELLION AGAINST THE HYPERREAL}

What initially triggers his transformation is his traumatic witnessing of Snowden's horrible death, an event which is consistently referred to throughout the novel but only described graphically near its end. In this chapter Yossarian is utterly incapable of even alleviating the pain of the severely wounded Snowden who was dying at the back of the plane. The Morphine syringes of the first-aid kit were stolen and replaced by a note which read: "What's good for M\&M Enterprise is good for the country, Milo Minderbinder" (Heller 298). Milo's note satirically echoes the kind of patriotic slogans which serve the interests of "the-powers-that-be." However, unlike Texan's comic patriotism there is nothing in Milo's note that could amuse Yossarian. Following this event, he starts to march backwards, naked, with his gun slung over his shoulder and refuses to fly more combat missions. Yossarian's disobedience is in complete defiance of military authority and is the starting point for his moral awakening. The 
awakening is complete when he hears about M.P.s raiding of a brothel he used to visit and flees to Rome to save the kid sister of Nately's whore who is now homeless. This chapter which is entitled "The Eternal City" narrates Yossarian failed attempt for finding the kid sister and graphically details the scenes of cruelty and inhumanity which he encounters on his journey through the city. As Heller himself explains this chapter is "a trip to the underground, a purgation from which Yossarian emerges. ... He is guilty and that is the beginning of his moral consciousness" (qtd in McDonald, Reading "Catch-22" 48). Yossarian's awakened moral consciousness forms the basis for his subversion of the hyperreal ideology. Hitherto, symptomatically speaking, Yossarian remained guilt-free and skeptical to values and principles and even prone to paranoia because the hegemony of hyperreal challenged the authenticity of all values and principles. Yet his "purgation" makes him take moral responsibility and thus turns him against this dominant discourse. He struggles to liberate himself from it, as it is reflected in his assertion that "every victim was a culprit, every culprit a victim, and somebody had to stand up sometime to try to break the lousy chain of inherited habit that was imperiling them all" (Heller 276). What he breaks is the lousy chain of "the business of illusion" which had him under his claws so far in the novel. By standing up for the principle of preserving the safety of a child (the kid sister) he liberates himself from the cynicism that hyperreality had installed in him. It is the first time in the novel that Yossarian is not obsessed with his own safety and survival; instead his mind is totally preoccupied with finding the homeless kid and helping her. The fact that the safety of the child is completely contrary to his own interests is highlighted by the fact that he moves to Rome to help the child without being on leave, something which he is finally arrested for. At this point Yossarian's status changes from antihero to hero since he is exhibiting a basic hallmark of heroism: sacrifice. This shift is due to his rebellion against the suppressing hyperreality which had denied him any moral clarity or certainty and had left him exclusively with nothing but constant fear of death. In Baudrillardian terminology, this act designates Yossarian as an agent of "Evil." This term does not have moral connotations in Baudrillard's vocabulary but rather denotes a structural critique of simulation: the world of simulation is completely bound up with what Baudrillard calls "the discourse of the Good" which "by whitewashing violence, by exterminating all germs and all of the accursed share, by performing cosmetic surgery on the negative" (The Transparency of Evil 81) attempts to muffle and eradicate Evil. Thus Evil becomes that which remains outside of simulation and threatens to destabilize it, "it is a structural critique of anything all-pervasive that emanates from simulation and a hygienised reality" (Hegarty 63). Therefore, by critiquing the moral 
indifference that emanates from this discourse Yossarian becomes a personification of the "principle of Evil." From this perspective, the fact that Yossarian gets arrested by M.P.s after his transformation is significant. Metaphorically, the M.P.s act as the agents of the hyperreal discourse tasked with arresting Yossarian precisely because of his subversion of its hegemony. In Yossarian's personification of "Evil" and the M.P.s metaphorical containment of this subversive force we find an allegory of an attempted rebellion against the hyperreality of postmodern life. From this perspective Heller's novel should be read and interpreted as a postmodern allegory that details an individual's struggles to escape from the post-truth relativism of a mentality which rejects certitudes in favor of perspectivism or, to put in Nietzschean terms, denies facts in favor of their interpretations. ${ }^{3}$ Yossarian is arrested by M.P.s while he is lecturing Aarfy on ethics and humanity. Aarfy had raped and murdered a young girl without any feeling of remorse and in response to Yossarian's reproaches condescendingly answers: "Oh, I had to do that after I raped her, I couldn't very well let her go around saying bad things about us, could I?" (Heller 268). The juxtaposition of Yossarian's strong sense of morality and condemning righteousness with Aarfy's casual indifference clearly illustrates Yossarian's break from the chains of indifference-oriented skepticism which he exhibited earlier in the novel. When the M.P. forces arrive Yossarian assumes that they are going to arrest Aarfy, but instead they arrest him for not having a pass and ironically apologize to Aarfy for intruding. Their apology to Aarfy makes perfect sense since Aarfy's indifference to his crime is totally in line with the malignant imperatives of the hyperreal which advocate the refutation of certitudes, including moral ones. From this perspective, there is no reason for arresting Aarfy but Yossarian's arrest is urgent: he is taken back to the headquarters to be reintegrated into the discourse of hyperreal and resume his previous skepticism. This is achieved by confronting him with the greatest of all moral challenges. $\mathrm{He}$ is taken to Colonel Korn and Colonel Cathcart's office where he is informed that they are going to send him home under one condition: he should "like" them. The fact that Yossarian is desperate to return to U.S. is evident, however, for fulfilling this wish he has to turn his back on all of those friends who died in the war since Colonel Cathcart and Korn are fully responsible for their deaths. Cathcart's zeal for promotion prompted him to increase endlessly the number of missions and to volunteer his squadron for any dangerous mission, which resulted in the death of some of Yossarian's most intimate friends such as Nately. Korn is no less blameless as he played the role of a persuader and the feeder of Cathcart's

3 "There are no facts, only interpretations." 
vanity. Additionally, they are frank about their evil quests and malignant nature, as evidenced in Korn's questioning Yossarian: "Won't you give up your life for Colonel Catchart and me?" (Heller 288). Although what they are asking for may seem ridiculously innocuous, they make no effort to hide the malicious connotations that underpin it: Korn openly reveals the moral dimensions connected to the deal when he informs Yossarian: "You're going to loathe it. It [the deal] really is odious and certainly will offend your conscience" (Heller 289). Furthermore, he also expresses his knowledge of Yossarian's moral awakening and his own lack of morality quite blatantly as he describes Yossarian as "an intelligent person of great moral character who has taken a very courageous stand," and himself as "an intelligent person with no moral character at all" (Heller 288). On an allegorical level, this scheme is staged to reintegrate Yossarian back into the framework of hyperreality and its "business of illusion" and to shatter his newly found sense of certitude and morality. In Baudrillardian terms, the whole scheme is designed to "save the reality principle," to once again screen Yossarian's eyes with an "ideological blanket" and alienate him from his newly found truth. What can be more effective in this regard than the charm of image?

We're going to promote you to major and even give you another medal. Captain Flume is already working on glowing press releases describing your valor over Ferrara, your deep and abiding loyalty to your outfit and your consummate dedication to duty. Those phrases are all actual quotations, by the way. We're going to glorify you and send you home a hero, recalled by the Pentagon for morale and public-relations purposes. You'll live like a millionaire. Everyone will lionize you. You'll have parades in your honor and make speeches to raise money for war bonds. (Heller 291, emphasis added)

Yossarian is initially deceived by these luring images and accepts being Cathcart and Korn's "pal," to like them and say good things about them. Nonetheless, the victory of "the business of illusion" is temporary and the antihero soon regains his previous heroic stance and cancels the deal. After being stabbed by Nately's girlfriend he is once again returned to the hospital where he is shaken awake and informed by a mysterious stranger that "we've got your pal, buddy" (295). At first he is totally baffled by this utterance and is incapable of comprehending its meaning, but later on in a moment of epiphany he understands it. He speculates that this "pal" must be a friend of his, such as Dunbar or Nately or "like Clevinger, Orr, Dobbs, Kid Sampson or McWatt" (297), someone he knew that was killed in the war. Then the epiphany dawns on him and he exclaims: "I just realized it, they've got all of my pals, haven't they?" (297).The 
unknown stranger and his mysterious message is a personification of the protagonist's conscience which is troubled by the "odious" deal and tries to awaken him. This reading is reinforced by the fact that Yossarian was asleep when he was visited by the stranger and falls to sleep again shortly after the encounter, and was quite delirious before that in the first place. He was visited by his own conscience which awakened him from his moral stupor. Finally, Yossarian calls off the deal, and, after learning that Orr was not dead and had carefully planned his escape to Sweden, he decides to desert the army too. Of course, in contrast to the common belief which was reinforced by the film adaptation of the novel, he did not intend to follow Orr. In an interview Heller explains how Yossarian's desertion is in line with his newly shaped heroic character and confirms the premise of this article:

Yossarian is running into danger, not away from it. He says there's a little girl in Rome whom he might be able to save. It's ironic that, after all the discussion about the ending of the novel, the film depicts Yossarian trying to row to Sweden. Nothing could have been farther from the case in the novel. (qtd in McDonald, Reading "Catch-22" 50)

\section{CONCLUSION}

In this article Paul McDonald's thesis that the universe of Joseph Heller's Catch-22 reflects the "second order of reality" that, according to Fredric Jameson, dominates American society was taken as a basic premise and, by drawing on Jean Baudrillard's theories on hyperreality, it was developed into a framework for studying the antiheroic character of the protagonist of the novel. It was argued that similar to Disneyland the island of Pianosa, where the events of Catch-22 take place, stands as a microcosm of the United States and mirrors its simulacral condition. The childish behavior of the top military officials and other army members who populate this island are in line with Baudrillard's belief regarding the rampant childishness which has dominated the American society of spectacle. The antiheroic status of the protagonist of the novel is also read as a direct result of his ideological conditioning within this context: Yossarian's "liver condition" embodies this, as it fluctuates between being jaundice and not being jaundice and defies the possibility of discerning the real from the non-real. This condition is symptomatic of what Baudrillard termed hyperreality, "substituting the signs of the real for the real" (4). Hyperreality is the foundation upon which the ideological edifice of the "business of illusion," which saturates the fictional context, is erected. Accordingly, the stance and the actions of 
Yossarian are regulated by its discourse and his antiheroic status is rooted in its hegemony. His indifference to pertinent ideals such as heroic patriotism or fighting against the evil of Nazism, which designates him as an antihero, is due to the fact that his subjectivity was ideologically blanketed by the hyperreal discourse and he looked at his surroundings through its lens. Thus, the possible authenticity of ideals such as patriotism, justice or heroism remained as elusive for him as distinguishing the authenticity of the symptoms of the soldier who saw everything twice, which, contrary to what Yossarian presumed, were not simulations. In other words, the truth-effacing side effects of hyperreality prevented the protagonist from having certitude about these abstract ideals. This point is especially well illustrated in his mocking contempt for the satirical patriotism of the Texan and Nately. Furthermore, it was contended that the change that occurs in Yossarian's status as an antihero and his final heroic stance was due to his rebellion against the hegemony of the hyperreal which had deadened him to certainty and moral integrity, as a result of which he becomes a personification of Baudrillardian "Evil," i.e. that which remains outside simulation and poses a threat to the hyperreal order. This rebellion leads to Yossarian transcending his antiheroic status and adopting a heroic one, as evidenced by his rejection of Korn and Cathcart's “odious" deal.

\section{Works CiTed}

Baudrillard, Jean. America. Trans. Chris Turner. London: Verso, 1989. Print.

---. Simulacra and Simulation. Trans. Sheila Glaser. Ann Arbor: U of Michigan P, 1994. Print.

---. The Transparency Of Evil. Trans. James Benedict. London: Verso, 2009. Print.

Debord, Guy. The Society of the Spectacle. New York: Zone, 1994. Print.

Hassan, Ihab. "The Antihero in Modern American and British Fiction."

Rumors of Change: Essays in Five Decades. Tuscaloosa: U of Alabama P, 1995. 50-75. Print.

Hegarty, Paul. "Evil." The Bandrillard Dictionary. Edinburgh: Edinburgh UP, 2010. 62-64. Print.

Heller, Joseph. Catch-22. Paris: B. Grasset, 1985. Print.

Horkheimer, Max, and Theodor W. Adorno. Dialectic of Enlightenment. New York: Herder, 1972. Print.

Jameson, Fredric. Postmodernism, or, the Cultural Logic of Late Capitalism.

Durham: Duke UP, 1991. Print.

Lane, Richard J. Jean Baudrillard. London: Routledge, 2000. Print. 
McDonald, Paul. Laughing at the Darkness: Postmodernism and Optimism in American Humor. Penrith: Humanities-Ebooks, 2010. Print.

---. Reading “Catch-22.” Penrith: Humanities-Ebooks, 2012. Print.

Pawlett, William. Jean Baudrillard: Against Banality. London: Routledge, 2007. Print.

Rubenstein, Diane. "America." The Baudrillard Dictionary. Edinburgh: Edinburgh UP, 2010. 11-13. Print.

Toffoletti, Kim. Baudrillard Reframed: Interpreting Key Thinkers for the Arts (Contemporary Thinkers Reframed Series). London: Tauris, 2011. Print.

Woodson, Jon. A Study of Joseph Heller's "Catch-22": Going Around Twice. New York: Peter Lang, 2001. Print.

Zaretsky, Robert. "Trump and the 'Society of the Spectacle." Nytimes.com. The New York Times 20 Feb. 2017. Web. 7 May 2017.

Žižek, Slavoj. The Fright of Real Tears: Krzysztof Kieślowski between Theory and Post-Theory. London: BFI, 2001. Print.

\section{Abdolali Yazdizadeh holds an MA in English literature from the University of Tehran. He is the author of "Tralfamadorian Utopia and the Logic of the Consumer Society: A Cultural Study of Kurt Vonnegut's Slaughterhouse-Five" (Australasian Journal of American Studies 36.1) and "Lacan as a Reader of Angela Carter's Bloody Chamber" (Studies in Literature and Language 16.2). yazdizadeh_ali@yahoo.com}

